\title{
Stratified Teaching Method of English Picture Book Reading in Primary Schools
}

\author{
Yidan $\mathrm{Xu}^{*}$ \\ School of Foreign Languages, Leshan Normal University, Leshan 614000, China \\ *Corresponding author: Yidan Xu, 18148089967@163.com
}

\begin{abstract}
With the advancement of the new curriculum reform, many schools have put forward the idea of combing English reading with stratified teaching. Enhancing the effectiveness of reading English picture books is an important goal that most English teachers uphold when reforming the teaching of English reading. In order to achieve this goal, it is necessary to improve the teaching methods of reading. Reading picture books is an important way to improve students' core competencies in English. However, at present, the method of teaching reading in primary school is simple; in addition, the teaching activities are not well organized. Therefore, in order to improve students' core competencies in English, this article points out several issues in the teaching of English picture book reading and provides some pedagogical implications for the teaching in this aspect based on the stratified teaching method and classroom observation by including Class 1, Grade 2 students from a primary school in Leshan as the research subjects.
\end{abstract}

Keywords: Stratified teaching; English picture book reading; Core competencies in English

Publication date: September 2021; Online publication: September 30, 2021

\section{Introduction}

The 2017 edition of English Curriculum Standard for Senior High Schools divides the core competencies in English into four aspects: language competence, cultural awareness, thinking quality, and learning ability. The English Curriculum Standard for Compulsory Education (2011) emphasizes that English curriculum in primary schools should follow the students' cognitive rules, provide curriculum resources that are close to students' life, and promote students' comprehensive language ability. English picture books, with vivid and intuitive graphic forms, can stimulate thinking, trigger language and content schemata in the minds of the students, as well as conform to the law of perception and thinking development.

Several scholars have proposed that picture books can help learners to understand the texts better and consolidate language learning ${ }^{[1]}$. However, influenced by traditional teaching concepts, some teachers still focus only on students' grammar and vocabulary learning; thus, the teaching effect is unsatisfactory. This in turn results in the shaping of a fixed mindset among students and more importantly, their learning and cognitive needs cannot be met effectively.

The three-dimensional objective (knowledge, ability, and emotion) integrates developmental evaluating strategies in English teaching, embodies the teaching concept of "all is for the development of students," reflects the epoch concepts of education, cultivates quality learners with ability, and accords with the tendency of evaluating development in modern international elementary education teaching. Emotional objectives should be emphasized in the teaching of English picture book reading in primary schools. Some teachers only design activities to impart basic information from English picture books, which lacks innovative questions about the emotional value contained in these picture books, thus hindering the improvement of learners' thinking ability. This also leads to the inadequate exploration of the educational 
value of English picture books as well as the lack of consistency and expansion in the use of these picture books.

Influenced by teacher-centered classroom, teachers often spoon-feed students on the content of picture books in line with their way of thinking. In that way, students rarely have the opportunity to express their understanding about the stories from the picture books, and they are not able to describe or perform the stories independently. In view of the above problems, how then should teachers apply the stratified teaching method into English picture book reading? In order to answer this question, this article would provide some pedagogical implications for teachers based on classroom observation.

\section{Literature review}

Researchers both at home and abroad have conducted studies on the subject of English picture books.

The research on picture books abroad started earlier. It involves a wide range, mainly from the perspectives of children's literature, early reading, teaching reading, library promotion, and art publishing. Nodelman attached great importance to the function of illustrations in picture books, where he pointed out that the major task of visual images in picture books is to communicate information and good picture books as a whole provide richer experience than just a simple sum of their parts ${ }^{[2]}$. Bader ${ }^{[3]}$ mainly classified and analyzed picture books from the 1940s to 1950 s in the United States from a historical perspective. In addition, Sutherland also explained that the trend of making picture books changed from entertaining to paying attention to children's world ${ }^{[4]}$.

Graded reading materials have been introduced into the learning of mother tongue, second language, and foreign language. Through empirical studies, many scholars have found that graded English reading can improve learners' reading quality, reading strategies, reading comprehension, and reading achievement. Japanese scholars have suggested that when selecting graded reading materials, readers' age, gender, character, and cultural background should be considered. Experts from the University of Oxford in the United Kingdom have spent 20 years researching graded reading of English picture books. From government agencies to school research institutions, a great deal of effort has been made to conduct scientific and systematic research of the development of children's English reading ability.

The research on English picture books by Chinese scholars started relatively late. According to relevant data from China National Knowledge Infrastructure (CNKI), only 15 literatures on the subject of "stratified teaching of English picture books" were found by June 2021. Building on Huang's observation ${ }^{\text {[5] }}$, the earliest literature on English picture books was published in 2000, which introduced and analyzed the themes, literary genres, and expression techniques of English picture books, and probed into its significance to English literature teaching. Among those literatures, many scholars have affirmed the value of English picture books, proved that picture books can help stimulate students' reading interest and improve their reading level, as well as shared the experience of instructional design of English picture book reading. However, these are mostly from experience, lacking the introduction of research methods, research questions, and corresponding theoretical frameworks.

Through the above analysis of the existing research results at home and abroad, the application of stratified teaching of English picture book reading in primary schools is not inadequate. Therefore, this article discusses about the application of this method in English picture book reading to improve students' core competencies in English.

\section{Theoretical framework}

Based on the stratified teaching method, this article discusses on how to apply this method to English picture book reading in primary schools. There are two important theories that cannot be disregarded; namely, 
stratified teaching and core competencies in English.

At the beginning of the 20th century, stratified teaching was first introduced in the United States. When the American government faced the influx of immigrant children, the education officials figured that it is necessary to teach these children with different backgrounds according to their abilities and past academic achievements. Since the 1980s, China has introduced the concept of stratified teaching. Many provinces and cities have carried out research and practice of stratified teaching in schools and have summed up the experience that is worthy of promotion and reference.

Stratified teaching means that teachers would divide students into several groups with similar levels according to their existing knowledge, ability, and potential. Through stratification strategies, these groups are able to better develop. Stratified teaching mainly embodies in the following four aspects: students' ability, teaching objectives, teaching activities, and teaching evaluation. Students' ability stratification involves the division of students into different groups and different teaching methods are adopted according to their individual differences. Stratified teaching objectives emphasize that the objectives need to be in line with the students' actual conditions; with different students, the teaching objectives should reflect certain differences. The stratification of teaching activities is embodied in the gradual transition from simple to complex activities, and from language knowledge to emotional value activities. In stratified teaching, because students have different levels of learning and academic achievements, stratified evaluating criteria should be adopted instead of using a single standard to evaluate students.

In 2014, the Ministry of Education first proposed to develop students' core competencies. The English Curriculum Standard for Senior High Schools divides the core competencies in English into four aspects: language competence, cultural awareness, thinking quality, and learning ability. Language competence is the ability to do things with language, involving knowledge, awareness, sense, skills of language, as well as communication strategies. Cultural awareness focuses on understanding the cultural connotation of different countries. Thinking quality is the ability of thinking and discrimination. Learning ability mainly includes meta-cognitive strategies, cognitive strategies, communication strategies, and emotional strategies.

\section{Research design}

This section mainly introduces the research design in this study. In the first part, the aim and questions of the research are put forward. The second part introduces the research participants. In the third part, the research method of classroom observation is introduced. The fourth part discusses the research procedures and finally, the analysis is carried out.

\subsection{Research aim and research question}

The issues faced in teaching English picture book reading have been pointed out. In order to solve these teaching problems, this study raised a research question: How to apply the stratified teaching method to English picture book reading in order to improve students' core competencies in English?

\subsection{Research participants and research method}

This study adopted the qualitative research method. Through classroom observation, students from Class 1 , Grade 2 of a primary school in Leshan were taken as the subjects in this study.

\subsection{Research procedure}

With the aforementioned subjects and method used in this study, the steps of the research were determined based on the aim. 
Step one: Students from Class 1, Grade 2 were included as the subjects in this study. Classroom observations were carried out in three English picture book reading classes. The three English picture books that were used in the reading classes were My First Chinese New Year, Puppy in a Box, and Sara's Medicine.

Step two: Three classroom observation scales were created. The title of English picture books, teaching activities, and teaching objectives were recorded.

Step three: The three classroom observation scales were collected, and a table was constructed based on the scales. Then, a survey report was written and the research question in this paper was answered by combining classroom observation, stratified teaching method, and literature retrieval.

\subsection{Data collection}

The data used in this research mainly comprised of three parts: (1) the title of the English picture books; (2) teaching activities; (3) teaching objectives. The data are provided as shown in Table 1, Table 2, and Table 3.

Table 1. Classroom observation on My First Chinese New Year

\begin{tabular}{ccc}
\hline Title & A & B \\
\hline My First Chinese New Year & No & No \\
\hline
\end{tabular}

Note: A. diversity of teaching activities; B. goal reaching degree.

Table 2. Classroom observation on Puppy in a Box

\begin{tabular}{cccc}
\hline Title & A & B \\
\hline Puppy in a Box & Yes & Yes \\
\hline
\end{tabular}

Note: A. diversity of teaching activities; B. goal reaching degree.

Table 3. Classroom observation on Sara's Medicine

\begin{tabular}{ccc}
\hline Title & A & B \\
\hline Sara's Medicine & No & No \\
\hline
\end{tabular}

Note: A. diversity of teaching activities; B. goal reaching degree.

\subsection{Data analysis}

From the two dimensions of the scale (diversity of teaching activities and goal reaching degree), Table 1 and Table 3 showed "No" in both aspects. This means that the teaching activities in both the classes lacked diversity and realization of the three-dimensional objective. Table $\mathbf{2}$ indicated "Yes," which infers that the teaching effect of this reading class was more effective.

Based on the two theoretical frameworks, the stratified teaching method and the core competencies in English, this article carries out an in-depth analysis of the research data.

Based on the data in Table 1 and Table 3, both reading classes had the same teaching problems; that is, the teaching activities are single, and the teaching objectives cannot be fully achieved. This situation is similar to what Li had observed, whereby the teaching of English reading in primary schools is still dominated by a single teaching form, which affects the teaching effect of English picture books ${ }^{[6]}$. Based on the classroom observation of My First Chinese New Year, the teacher only designed a role-play activity and even after the students had performed, the teacher did not provide any targeted evaluation. In the third English picture book reading class (Sara's Medicine), the teacher only paid attention to language points, 
such as sentence patterns and some vocabulary, instead of designing open-ended questions to cultivate students' thinking ability. There are cases where some teachers would evaluate the teaching effect through examination but fail to pay enough attention to their students' emotional world ${ }^{[7]}$. According to the data in Table 2, it was found that in this English picture book reading class (Puppy in a Box), the teacher designed teaching activities, such as role-playing, painting, and singing. According to Yang, role-playing activities in English picture book reading classes can deepen the understanding of the story and correct mispronunciations through dialogue ${ }^{[8]}$. Through the collection and analysis of the above data, relevant pedagogical implications for the teaching of English picture book reading would be discussed in the next section.

\section{Conclusion}

In this section, this article summarizes the research question and research findings again as well as points out the limitations of the research.

Based on the stratified teaching method and by taking second-year students from a primary school in Leshan as the subjects in this study, several teaching problems that exist in English picture book reading classes are pointed out. Through the observation of three picture book reading classes in this study, it was found that the teaching activities in those classes were single, and the teaching objectives could not be fully realized. Therefore, in view of these teaching problems, there are several relevant pedagogical implications: (1) teachers should design more teaching activities, such as role-playing, painting, and singing, to stimulate students' interest and trigger their prior knowledge; (2) English picture book reading classes can be divided into three stages, thus making the teaching structure more organized; (3) teachers should attach great importance to the realization of emotional objectives.

On the other hand, there are some limitations in this study. The research method applied in this research is inadequate. While this research had only adopted classroom observation as its research method, other methods including interviews, questionnaires, and experiments are expected to be used to ensure the results obtained from the research more comprehensive.

In the future, researchers should further explore on how to apply the stratified teaching method to English picture book reading classes. Besides that, phonics can also be combined with English picture books, and it would be beneficial for Chinese scholars to put in effort to develop English graded picture books that are suitable for Chinese children.

\section{Disclosure statement}

The author declares that there is no conflict of interest.

\section{References}

[1] Smallwood BA, 1988, Children's Literature for Limited English Proficient Students, Ages 9-14, ERIC Clearinghouse, Washington, D.C., 22.

[2] Nodelman P, 1988, Word about Pictures: The Narrative Art of Children's Picture Books, University of Georgia Press, Athens.

[3] Bader, 1976, The Library Quarterly: Information, Community, Policy. The University of Chicago Press, 49(1): 107-108.

[4] Sutherland Z, 1979, American Picture Books: From Noah's Ark to the Beast Within by Barbara, Macmillan Pub Co. 
[5] Huang X, 2013, Reading English Picture Books from the Perspective of Experience Philosophy. Young Writers, (4): 36-39.

[6] Li C, 2018, Application Dilemma and Countermeasures in English Picture Book Teaching. Teaching and Management, (20): 51-53.

[7] Jiang L, 2018, The Design of Open Reading Activities of English Picture Books in Primary Schools. Teaching and Management, (8): 44-46.

[8] Yang L, 2019, Strategies for Teaching Design of English Picture Books in Primary Schools. Teaching and Management, (29): 49-50.

[9] Ghosn IK, 2002, Four Good Reasons to Use Literature in Senior Grade Primary School ELT. English Language Teaching Journal, 56(2): 172-179.

[10] Niblack RA, 1995, Art Criticism: A Whole Language Approach to Art, Macmillan, London.

[11] Harrington JM, 2016, "We're All Kids!" Picture Books and Cultural Awareness. The Social Studies, 107(6): 244-256.

[12] Gong W, 2013, On the Effective Integration of English Picture Books and Oxford Textbooks. Reading, (28): 25-27.

[13] Wang Q, Ao N, 2017, Approaches and Methods of English Picture Book Teaching in Primary and Secondary Schools. Curriculum Teaching Materials Teaching Method, (4): 68-73.

[14] Xu X, 2018, Effective Teaching Strategies for English Picture Book Reading. Teaching and Management, (29): 48-50.

[15] Ministry of Education of the People's Republic of China, 2011, English Curriculum Standards for Compulsory Education (2011 Edition), Beijing Normal University Press, Beijing.

[16] Ministry of Education of the People's Republic of China, 2017, English Curriculum Standards for Ordinary Senior High Schools (2017 Edition), People's Education Press, Beijing. 